\title{
KONTRIBUSI LINGKUNGAN SEKOLAH, EFIKASI DIRI DAN KECERDASAN EMOSIONAL TERHADAP HASIL BELAJAR SIMULASI DAN KOMUNIKASI DIGITAL SISWA KELAS X DI SMKN 6 PADANG
}

\author{
Dianne Wira Suryani ${ }^{1}$, Prof. Dr. Jalius Jama, M.Ed ${ }^{2}$ \\ ${ }^{1,2}$ Fakultas Teknik, Universitas Negeri Padang \\ diannewira0993.upiyptk@gmail.com ${ }^{1}$, jaliusjama@yahoo.co.id ${ }^{2}$
}

\begin{abstract}
ABSTRAK
Penelitian ini bertujuan untuk: 1) Menjelaskan hubungan lingkungan sekolah terhadap hasil belajar Simulasi dan Komunikasi Digital siswa kelas X di SMKN 6 Padang, 2) Menjelaskan hubungan efikasi diri terhadap hasil belajar Simulasi dan Komunikasi Digital siswa kelas X di SMKN 6 Padang, 3) Menjelaskan hubungan kecedasan emosional terhadap hasil belajar Simulasi dan Komunikasi Digital siswa kelas X di SMKN 6 Padang, 4) Menjelaskan hubungan lingkungan sekolah, efikasi diri dan kecerdasan emosional secara bersama-sama terhadap hasil belajar Simulasi dan Komunikasi Digital siswa kelas X di SMKN 6 Padang. Berdasarkan hasil penelitian, didapatkan bahwa data normal, linier dan tidak terjadi multikolinieritas. Hasil pengujian pada taraf signifikansi $\alpha 0,05$ (taraf kepercayaan 95\%) didapatkan nilai rxly sebesar 0,593 dengan rtabel 0,2158 karena rhitung $>$ rtabel maka hipotesis pertama diterima. Kemudian nilai rx2y sebesar 0,655 dengan rtabel 0,2158, karena rhitung> rtabel maka hipotesis kedua diterima. Kemudian nilai rx3y sebesar 0,476 dengan rtabel 0,2158, karena rhitung $>$ rtabel maka hipotesis ketiga diterima. Selanjutnya nilai rx1x2x3y sebesar 0,716 dengan rtabel 0,2158, karena rhitung $>$ rtabel maka hipotesis keempat diterima. Dan didukung oleh nilai Fhitung $=27,721$ dan Ftabel $=2,718$ sehingga diperoleh Fhitung $>$ Ftabel $(27,721>2,718)$.
\end{abstract}

Kata kunci : Efikasi Diri, Kecerdasan Emosional, Lingkungan Sekolah.

\section{Pendahuluan}

Hasil belajar dapat dikatakan sebagai tolak ukur sejauh mana keberhasilan yang telah dicapai oleh seseorang. Jadi, dapat dikatakan bahwa hasil belajar memiliki makna sebagai hasil maksimum yang diraih peserta didik dari usaha yang telah dilakukannya dalam proses belajar [1]. Beberapa faktor yang memberikan dampak kepada hasil belajar siswa antara lain adalah (1) faktor-faktor internal, dan (2) faktor eksternal. Faktor yang berasal dari dalam diri siswa dan memberikan dampak kepada hasil belajar siswa atau secara internal mencakup aspek fisiologis (kondisi fisik dan panca indera) dan aspek psikologis (efikasi diri, minat, bakat, motivasi, kematangan, emosi, kesiapan dan kemampuan kognitif). Selanjutnya faktor yang berasal dari luar diri siswa dan dapat mempengaruhi hasil belajar siswa atau faktor eksternal yang mencakup aspek sosial (sekolah, masyarakat, keluarga dan kelompok), aspek budaya, aspek lingkungan fisik (fasilitas rumah, fasilitas belajar, instrumen sekolah seperti kumpulan bahan pelajaran, pengajar, saran dan prasarana, administrasi atau manajemen) dan juga aspek lingkungan spiritual atau keagamaan [2]. Pada penelitian ini peneliti memiliki focus yaitu satu faktor yang berasal dari luar diri siswa yang memberikan dampak terhadap hasil belajar berupa lingkungan sekolah serta dua 
faktor internal berupa efikasi diri dan kecerdasan emosional.

Lingkungan sekolah dimaknai sebagai tempat pelaksanaan pembelajaran yang kedua sesudah lingkungan keluarga. Peserta didik, pengajar, staff administrasi dan BK berdampingan serta melakukan pendidikan secara runtut dan penuh perancanaan [3]. Lingkungan sekolah merupakan salah satu faktor yang turut mempengaruhi pertumbuhan dan perkembangan anak terutama untuk kecerdasannya [4].

Kondisi lingkungan sekolah yang mempengaruhi kondisi belajar antara lain adanya guru dalam jumlah yang cukup memadai sesuai dengan jumlah bidang studi yang ditentukan, peralatan yang cukup lengkap, gedung sekolah yang memenuhi persyaratan bagi berlangsungnya proses belajar yang baik, adanya teman yang baik, adanya keharmonisan hubungan semua personil disekolah, adanya disiplin dan tata tertib yang ditegakan secara konsekuen dan konsisten [5]. Selain faktor eksternal, terdapat juga faktor internal berupa efikasi diri dan kecerdasan emosional.

Efikasi diri dimaknai sebagai suatu kepercayaan seseorang tentang kemampuan dirinya sendiri ketika melaksanakan tugas atau kegiatan yang dibutuhkan demi meraih tujuan yang diinginkan [6]. Selanjutnya efikasi diri dapat dimaknai sebagai hasil penilaian seseorang terhadap kecakapan atau kemampuan yang dimilikinya untuk melakukan tugas tertentu, untuk menggapai tujuan dan menghilangkan hambatan [7]. Efikasi diri dimaknai sebagai suatu hubungan antara lingkungan luar, teknik penyelarasan diri serta kemampuan personal, pengalaman dan pendidikan [8]. Faktor berikutnya yaitu kecerdasan emosional. Kecerdasan emosional adalah kemampuan untuk mengenali perasaan kita sendiri dan orang lain, kemampuan untuk memotivasi diri sendiri dan kemampuan untuk mengelola emosi dengan baik pada diri sendiri dan dalam hubungan/berinteraksi dengan orang lain [9].

Berdasarkan observasi yang peneliti lakukan terhadap SMKN 6 Padang, diperoleh beberapa informasi bahwa hasil belajar Simulasi dan Komunikasi Digital siswa kelas X di SMKN 6 Padang tersebut masih dikatakan rendah. Hal ini dibuktikan dengan nilai ujian ulangan harian (UH) peserta didik kelas $\mathrm{X}$ pada bidang studi Simulasi dan Komunikasi Digital yang masih berada di bawah standar ketuntasan minimum, yaitu di bawah 75. dari 528 orang siswa kelas X di SMKN 6 Padang, terdapat $46,21 \%$ atau 244 siswa yang mencapai standar ketuntasan minimum yang telah ditetapkan. Sedangkan 53,79\% siswa lainnya meraih nilai di bawah standar ketuntasan minimum. Data tersebut memperlihatkan bahwa masih banyak siswa yang mempunyai nilai yang di bawah ratarata.

Melalui kegiatan observasi dan pengamatan langsung yang peneliti lakukan, didapatkan informasi bahwa banyak siswa yang memiliki tingkat efikasi yang minim. Dapat dibuktikan dengan siswa yang kurang percaya diri dalam presentasi di depan kelas, kurang yakin dalam mengutarakan ide atau pendapat saat berdiskusi, tidak mau memberikan pertanyaan kepada guru mengenai materi yang dirasa kurang paham. Selain masalah efikasi diri siswa tersebut, peneliti juga menemukan bahwa kebanyakan siswa kelas $\mathrm{X}$ di SMKN 6 Padang memiliki emosi yang masih kurang stabil. Dimana masih banyak siswa yang mudah terpancing emosi dalam diskusi, mudah berubah-ubah situasi hatinya untuk mengikuti proses belajar mengajar dan berbagai sikap siswa lainnya 
yang menggambarkan kecerdasan emosional yang rendah.

Selain masalah-masalah yang berasal dari dalam tersebut, peneliti juga menemukan masalah eksternal berupa lingkungan sekolah. Berdasarkan pengamatan langsung yang dilaksanakan kepada siswa kelas X di SMKN 6 Padang selaku objek penelitian, diperoleh informasi bahwa kurang kondusifnya lingkungan sekolah menyebabkan siswa kurang fokus dalam mengikuti proses pembelajaran. Peneliti mengamati banyaknya siswa yang memiliki hasil belajar rendah, karena disekolah tersebut masih kurangnya kenyamanan lingkungan belajar siswa dan kurangnya pemantauan guru kepada siswa ketika pembelajaran berlangsung, dibuktikan melalui beberapa siswa yang izin keluar kelas dengan bermacam-macam alasan. Hal tersebut secara tidak langsung menggambarkan suasana kelas kurang nyaman dan menyebabkan siswa keluar kelas pada pada saat jam pelajaran berlangsung.

Berdasarkan beberapa masalah yang telah dikemukakan diatas, maka peneliti ingin meneliti masalah tersebut ke dalam sebuah penelitian yang berjudul "Kontribusi Lingkungan Sekolah, Efikasi Diri dan Kecerdasan Emosional Terhadap Hasil belajar Simulasi dan Komunikasi Digital Siswa Kelas X di SMKN 6 Padang.”.

\section{Metode Penelitian}

Jenis Penelitian ini menggunakan metode penelitian kuantitatif dengan jenis penelitian korelasional. Metode penelitian kuantitatif ialah sebuah metode yang berhakikatkan pada filsafat keefektivan, dimanfaatkan demi melaksanakan penelitian terhadap populasi atau sampel tertentu, data yang dikumpulkan dimanfaatkan sebagai instrumen penelitian, analisa data bersifat kuantitatif, bertujuan demi melaksanakan pengujian hipotesis yang sudah ditentukan [10]. Sedangkan penelitian korelasional dimaknai sebagai suatu penelitian yang memungkinkan untuk memprediksi skor tertentu dikarenakan adanya skor yang lain dan menjelaskann antar variabel [11].

Penelitian ini dilakukan di SMKN 6 Padang. Penelitian ini dilakukan pada semester ganjil tahun pelajaran 2020/2021. Populasi yang digunakan pada penelitian ini ialah keseluruhan peserta didik kelas $\mathrm{X}$ di SMKN 6 Padang yang jumlahnya 488 orang siswa. Pada penelitian ini, teknik pengambilan sampel yang digunakan adalah proporsional random sampling yakni teknik demi meraih sampel yang langsung dilaksanakan pada tiap unit sampling yang tergabung sebagai bahagian palimg kecil dalam penentuan besar sampel, Berdasarkan penarikan sampel yang dijabarkan tersebut, sampel terpilih sejumlah 83 orang peserta didik. Instrumen ialah alat yang dimanfaatkan demi memperoleh data pada suatu penelitian dan penilaian. Instrumen ialah alat ukur yang dimanfaatkan demi meraih informasi kuantitatif mengenai variasi karakteristik variabel penelitian secara objektif. Instrumen yang dimanfaatkan pada penelitian ini yakni angket dan tes hasil belajar.

\section{Hasil dan Pembahasan}

Pada bagian deskripsi data ini diuraikan secara detail mengenai kontribusi lingkungan sekolah, efikasi diri dan kecerdasan emosional terhadap hasil belajar simulasi dan komunikasi digital siswa kelas $\mathrm{X}$ di SMK Negeri 6 Padang. Pada penelitian ini yang dijadikan objek penelitian adalah seluruh siswa di SMKN 6 Padang. Populasi yang digunakan pada penelitian ini ialah keseluruhan peserta didik kelas $\mathrm{X}$ di SMK Negeri 6 Padang yang jumlahnya 488 orang siswa. Setelah dilakukan penarikan sampel secara proporsional random sampling, maka diperoleh sampel sebanyak 83. Seluruh data hasil penelitian yang masuk dan memenuhi syarat, diolah dan dianalisis untuk mengungkapkan informasi sesuai dengan 
tujuan penelitian. Secara singkat dapat dinyatakan bahwa deskripsi data penelitian variabel $\mathrm{X}_{1}, \mathrm{X}_{2}, \mathrm{X}_{3}$, dan $\mathrm{Y}$ dapat dilihat pada tabel 1:

Tabel 1 Data Responden Variabel $\left(\mathrm{X}_{1}\right)$, $\left(\mathrm{X}_{2}\right),\left(\mathrm{X}_{3}\right)$ dan (Y)

\begin{tabular}{|c|c|c|c|c|c|}
\hline & & $\mathrm{X} 1$ & $\mathrm{X} 2$ & $\mathrm{X} 3$ & $\mathrm{Y}$ \\
\hline \multirow{2}{*}{$\mathrm{N}$} & Valid & 83 & 83 & 83 & 83 \\
\hline & Missing & 0 & 0 & 0 & 0 \\
\hline \multicolumn{2}{|c|}{ Mean } & 149,1566 & 128,0000 & 135,1566 & 23,9398 \\
\hline \multicolumn{2}{|c|}{ Median } & 149,0000 & 128,0000 & 135,0000 & 24,0000 \\
\hline \multicolumn{2}{|c|}{ Mode } & 149,00 & 128,00 & 135,00 & 24,00 \\
\hline \multicolumn{2}{|c|}{ Std, Deviation } & 18,60664 & 16,44503 & 16,51421 & 2,83854 \\
\hline \multicolumn{2}{|c|}{ Variance } & 346,207 & 270,439 & 272,719 & 8,057 \\
\hline \multicolumn{2}{|c|}{ Range } & 80,00 & 74,00 & 74,00 & 14,00 \\
\hline \multicolumn{2}{|c|}{ Minimum } & 110,00 & 90,00 & 99,00 & 16,00 \\
\hline \multicolumn{2}{|c|}{ Maximum } & 190,00 & 164,00 & 173,00 & 30,00 \\
\hline \multicolumn{2}{|c|}{ Sum } & 12380,00 & 10624,00 & 11218,00 & 1987,00 \\
\hline
\end{tabular}

Hasil penelitian ini dilaporkan sesuai dengan tujuan yang telah diajukan dalam penelitian. Selanjutnya untuk melihat kontribusi lingkungan sekolah, efikasi diri dan kecerdasan emosional terhadap hasil belajar simulasi dan komunikasi digital siswa kelas X di SMK Negeri 6 Padang. maka dilakukan Pengujian hipotesis dilaksanakan dengan uji t secara parsial dan secara simultan. Persyaratan analisis yang perlu dipenuhi berupa uji normalitas, linieritas dan multikolinieritas. Uji Normalitas menggunakan teknik analisis Kolmogorav-Smirnov Test dengan program SPSS versi 21 pada probabilitas $\alpha=0,05$. Hasil perhitungan uji normalitas keempat variabel tersebut disajikan pada tabel 2:

Tabel 2. Hasil Uji Normalitas Variabel

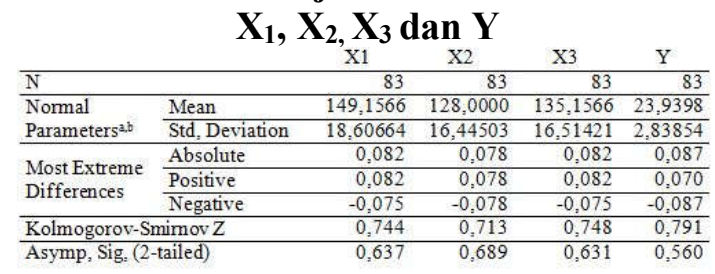

Tabel 2 menunjukkan probabilitas (sign) keempat variabel $>\alpha=0,05$. Probabilitas (sign) variabel lingkungan sekolah $\left(\mathrm{X}_{1}\right)$ sebesar 0,637 , variabel efikasi diri $\left(\mathrm{X}_{2}\right)$ sebesar 0,689 , variabel kecerdasan emosional $\left(\mathrm{X}_{3}\right)$ sebesar 0,631 dan variabel hasil belajar (Y) sebesar 0,560. Dengan demikian dapat disimpulkan bahwa $\mathrm{Ha}$ diterima dan berdasarkan hasil analisis tersebut dapat dinyatakan bahwa data keempat variabel berdistribusi normal. Hal ini menunjukkan bahwa salah satu syarat untuk pengujian hipotesis sudah dipenuhi.

Uji linieritas dilakukan untuk melihat apakah masing-masing data variabel lingkungan sekolah $\left(\mathrm{X}_{1}\right)$, efikasi diri $\left(\mathrm{X}_{2}\right)$, kecerdasan emosional $\left(\mathrm{X}_{3}\right)$ cenderung membentuk kontribusi garis linear terhadap variabel hasil belajar (Y). Hasil perhitungan uji linieritas variabel lingkungan sekolah $\left(\mathrm{X}_{1}\right)$, efikasi diri $\left(\mathrm{X}_{2}\right)$, kecerdasan emosional $\left(\mathrm{X}_{3}\right)$ terhadap variabel hasil belajar $(\mathrm{Y})$ disajikan pada tabel 3,4, dan 5:

Tabel 3. Hasil Uji Linieritas Variabel $\mathrm{X}_{1}$ dan $\mathbf{Y}$

\begin{tabular}{lllrr}
\hline & & \multicolumn{2}{c}{ F } & \multicolumn{1}{c}{ Sig, } \\
\hline \multirow{4}{*}{$\mathrm{Y}^{*} \mathrm{X} 1$} & $\begin{array}{l}\text { Between } \\
\text { Groups }\end{array}$ & (Combined) & 10,718 & 0,000 \\
\cline { 2 - 4 } & & $\begin{array}{l}\text { Linearity } \\
\text { Deviation from }\end{array}$ & 69,767 & 0,000 \\
\cline { 2 - 4 } & Linearity & 5,350 & 0,000 \\
\cline { 2 - 4 } & \multicolumn{3}{c}{ Within Groups } & \\
\hline
\end{tabular}

Berdasarkan tabel 3 di atas, diperoleh probabilitas linearity (sign) sebesar 0,000 lebih kecil dari 0,05 maka dapat disimpulkan bahwa sebaran data variabel bebas membentuk garis linear terhadap variabel terikat.

Tabel 4. Hasil Uji Linieritas Variabel

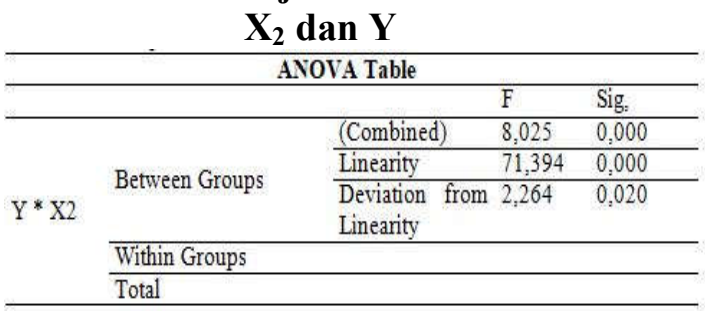

Berdasarkan tabel 4 di atas, diperoleh probabilitas linearity (sign) sebesar 0,000 lebih kecil dari 0,05 maka dapat 
disimpulkan bahwa sebaran data variabel bebas membentuk garis linear terhadap variabel terikat.

Tabel 5. Hasil Uji Linieritas Variabel $X_{3}$

\begin{tabular}{|c|c|c|c|c|}
\hline & & ANOVA Table & & \\
\hline & & & F & Sig, \\
\hline \multirow{6}{*}{$\mathrm{Y} * \mathrm{X} 3$} & \multirow{4}{*}{ Between Groups } & (Combined) & 9,906 & 0,000 \\
\hline & & Linearity & 42,752 & 0,000 \\
\hline & & Deviation & 6,920 & 0,000 \\
\hline & & Linearity & & \\
\hline & Within Groups & & & \\
\hline & Total & & & \\
\hline
\end{tabular}

Berdasarkan tabel 5 di atas, diperoleh probabilitas linearity (sign) sebesar 0,000 lebih kecil dari 0,05 maka dapat disimpulkan bahwa sebaran data variabel bebas membentuk garis linear terhadap variabel terikat. Karena pengujian linieritas telah terpenuhi, maka dapat dilanjutkan dengan uji multikolinieritas.

Uji multikolonieritas bertujuan untuk menguji apakah model regresi ditemukan adanya korelasi antar variabel bebas (independen). Uji multikolinieritas dapat digunakan untuk mengetahui ada atau tidaknya penyimpangan asumsi klasik. Multikolinieritas yaitu adanya hubungan linear antara variabel independen dalam model regresi. Prasayarat yang harus terpenuhi, dalam model regresi adalah tidak adanya multikolinieritas (Ghozali, 2011:105). Uji multikolinieritas dilaksanakan dengan analisis regresi auxiliary menggunakan bantuan program IBM SPSS versi 21.0. Berdasarkan pengujian multikolinieritas yang telah dilakukan, maka diperoleh hasil sebagai berikut:

Tabel 6. Uji Multikolinieritas

\begin{tabular}{lll}
\hline Variabel Independen & \multicolumn{1}{c}{ Variabel Dependen } & Nilai $r$ square $\left(\mathbf{r}^{2}\right)$ \\
\hline $\mathrm{X} 1$ & $\mathrm{X} 2$ & 0,658 \\
\hline $\mathrm{X} 2$ & $\mathrm{X} 3$ & 0,344 \\
\hline $\mathrm{X} 3$ & $\mathrm{X} 1$ & 0,527 \\
\hline Nilai $\mathrm{R}^{2}$ & 0,716 & \\
\hline
\end{tabular}

Berdasarkan tabel di atas dapat diketahui bahwa nilai koefisien $\mathrm{r}^{2}$ yang diperoleh seluruhnya bernilai lebih kecil dari pada nilai koefisien determinasi $\left(\mathrm{R}^{2}\right)$. Dengan demikian dapat disimpulkan bahwa tidak terjadi masalah multikolinearitas pada model regresi, Maka dapat dilanjutkan dengan uji hipotesis.

a. Hipotesis pertama

Hipotesis pertama pada penelitian ini yakni terdapat kontribusi antara Lingkungan sekolah dengan hasil belajar di SMKN 6 Padang. Hipotesis tersebut diuji menggunakan teknik regresi sederhana dengan metode stepwise (stepwise method). hasilnya yaitu :

Tabel 7. Hasil Analisis Korelasi Sederhana Variabel $X_{1}$ dengan $Y$ MenggunakanTabel Coefficient

\begin{tabular}{|c|c|c|c|c|c|}
\hline \multicolumn{6}{|c|}{ Coefficients $^{\mathrm{a}}$} \\
\hline \multirow[t]{3}{*}{ Model } & Unstanc & dardized & Standardized & $\mathrm{t}$ & Sig, \\
\hline & Coeff & icients & Coefficients & & \\
\hline & $B$ & Std, Error & Beta & & \\
\hline \multirow{2}{*}{$1 \frac{\text { (Constant) }}{\mathrm{X} 1}$} & 10,454 & 2,052 & & 5,094 & 0,000 \\
\hline & 0,090 & 0,014 & 0,593 & 6,622 & 0,000 \\
\hline
\end{tabular}

Jika nilai $t_{\text {hitung }}>t_{\text {tabel, }}$ maka terdapat hubungan yang signifikan, apabila $t_{\text {hitung }}<t_{\text {tabel }}$ maka tidak terdapat hubungan yang signifikan. Nilai $t_{\text {tabel }}$ pada alpha $5 \%$ adalah $\mathrm{dk}=$ $\mathrm{N}-3$ atau $\mathrm{dk}=83-3=80$, nilai $\mathrm{t}_{\text {tabel }}$ yaitu 1,990. Apabila dibandingkan $t_{\text {hitung }} 6,622$ dengan $t_{\text {tabel }} 1,990$, maka dapat diketahui bahwa nilai $t_{\text {hitung }}>t_{\text {tabel. }}$. Maka dari itu dapat disimpulkan bahwa terdapat hubungan antara lingkungan sekolah dengan hasil belajar di SMKN 6 Padang.

b. Hipotesis kedua

$$
\text { Hipotesis kedua pada }
$$
penelitian ini yakni terdapat kontribusi antara efikasi diri dengan hasil belajar di SMKN 6 Padang. Hipotesis tersebut diuji menggunakan teknik regresi sederhana dengan metode stepwise (stepwise method). Hasilnya yaitu : 


\begin{abstract}
Tabel 8. Hasil Analisis Korelasi Sederhana Variabel $\mathbf{X}_{2}$ dengan $Y$ Menggunakan Tabel Coefficient

\begin{tabular}{|c|c|c|c|c|c|}
\hline \multirow{2}{*}{$\overline{\text { Model }}$} & \multicolumn{4}{|c|}{ Coefficients" } & \multirow{3}{*}{ Sig; } \\
\hline & \multicolumn{2}{|c|}{$\begin{array}{l}\text { Unstandardized } \\
\text { Coefficients }\end{array}$} & $\begin{array}{l}\text { Standardized } \\
\text { Coefficients }\end{array}$ & $\mathrm{t}$ & \\
\hline & B & Std, Error & Beta & & \\
\hline (Constant) & 9,464 & 1,870 & & 5,062 & 0,0 \\
\hline $1 \overline{\mathrm{X} 2}$ & 0,113 & 0,014 & 0,655 & 7,806 & 0,0 \\
\hline
\end{tabular}

Jika nilai $t_{\text {hitung }}>t_{\text {tabel, }}$ maka terdapat hubungan yang signifikan, apabila $\mathrm{t}_{\text {hitung }}<\mathrm{t}_{\text {tabel }}$ maka tidak terdapat hubungan yang signifikan. Nilai $t_{\text {tabel }}$ pada alpha $5 \%$ adalah $\mathrm{dk}=\mathrm{N}-3$ atau $\mathrm{dk}=83-3=80$, nilai $\mathrm{t}_{\text {tabel }}$ yaitu 1,990 . Apabila dibandingkan $t_{\text {hitung }} 7,806$ dengan $t_{\text {tabel }} 1,990$, maka dapat diketahui bahwa nilai $t_{\text {hitung }}>t_{\text {tabel. }}$. Maka dari itu dapat disimpulkan bahwa terdapat hubungan antara efikasi diri dengan hasil belajar di SMKN 6 Padang.
\end{abstract}

\section{c. Hipotesis ketiga}

Hipotesis ketiga pada penelitian ini yakni terdapat kontribusi antara kecerdasan emosional dengan hasil belajar di SMKN 6 Padang. Hipotesis tersebut diuji menggunakan teknik regresi sederhana dengan metode stepwise (stepwise method).. Hasilnya yaitu :

Tabel 9. Hasil Analisis Korelasi Sederhana Variabel $\mathrm{X}_{3}$ dengan $\mathrm{Y}$ Menggunakan Tabel Coefficient

\begin{tabular}{|c|c|c|c|c|c|}
\hline \multirow{3}{*}{ Model } & \multicolumn{4}{|c|}{ Coefficients $^{2}$} & \multirow{3}{*}{ Sig, } \\
\hline & \multicolumn{2}{|c|}{$\begin{array}{l}\text { Unstandardized } \\
\text { Coefficients }\end{array}$} & $\begin{array}{l}\text { Standardized } \\
\text { Coefficients }\end{array}$ & $\mathrm{t}$ & \\
\hline & B & Std, Error & Beta & & \\
\hline (Constant) & 12,887 & 2,287 & & 5,635 & 0,000 \\
\hline $\mathrm{X} 3$ & 0,082 & 0,017 & 0,476 & 4,868 & 0,000 \\
\hline
\end{tabular}

Jika nilai $t_{\text {hitung }}>t_{\text {tabel }}$, maka terdapat hubungan yang signifikan, apabila $\mathrm{t}_{\text {hitung }}<\mathrm{t}_{\text {tabel }}$ maka tidak terdapat hubungan yang signifikan. Nilai $t_{\text {tabel }}$ pada alpha $5 \%$ adalah $\mathrm{dk}=\mathrm{N}-3$ atau $\mathrm{dk}=83-3=80$, nilai $\mathrm{t}_{\text {tabel }}$ yaitu 1,990. Apabila dibandingkan $t_{\text {hitung }} 4,868$ dengan $t_{\text {tabel }} 1,990$, maka dapat diketahui bahwa nilai $t_{\text {hitung }}>t_{\text {tabel. }}$. Maka dari itu dapat disimpulkan bahwa terdapat hubungan antara kecerdasan emosional dengan hasil belajar di SMKN 6 Padang.

\section{d. Hipotesis keempat}

Hipotesis keempat pada penelitian ini yakni terdapat kontribusi antara lingkungan sekolah, efikasi diri dan kecerdasan emosional secara bersama-sama terhadap hasil belajar simulasi dan komunikasi digital siswa kelas $\mathrm{X}$ di SMK Negeri 6 Padang. Hipotesis tersebut diuji menggunakan teknik korelasi berganda

\section{Tabel 10. Hasil Analisis Regresi Ganda Variabel $X_{1}, X_{2}$ dan $X_{3}$ Terhadap $Y$ Menggunakan Tabel Coefficient

\begin{tabular}{|c|c|c|c|c|c|}
\hline \multirow{3}{*}{ Model } & \multicolumn{4}{|c|}{ Coefficients $s^{a}$} & \multirow{3}{*}{ Sig, } \\
\hline & \multicolumn{2}{|c|}{$\begin{array}{l}\text { Unstandardized } \\
\text { Coefficients }\end{array}$} & $\begin{array}{l}\text { Standardized } \\
\text { Coefficients }\end{array}$ & $t$ & \\
\hline & B & Std, Error & Beta & & \\
\hline (Constant) & 4,553 & 2,209 & & 2,062 & 0,043 \\
\hline $\mathrm{X} 1$ & 0,025 & 0,018 & 0,164 & 1,422 & 0,159 \\
\hline $\mathrm{X} 2$ & 0,081 & 0,018 & 0,469 & 4,495 & 0,000 \\
\hline $\mathrm{X} 3$ & 0,039 & 0,016 & 0,228 & 2,469 & 0,016 \\
\hline
\end{tabular}

Berdasarkan hasil analisis koefisien regresi lingkungan sekolah $\left(\mathrm{X}_{1}\right)$ efikasi diri $\left(\mathrm{X}_{2}\right)$, dan kecerdasan emosional $\left(\mathrm{X}_{3}\right)$ secara bersama-sama dengan hasil belajar (Y) diperoleh nilai signifikansi sebesar 0,043 dengan nilai konstanta 4,553 sedangkan koefisien persamaan regresi ganda yang dihasilkan adalah $\hat{\mathrm{Y}}=\mathrm{a}+\mathrm{b}_{1} \mathrm{X}_{1}+\mathrm{b}_{2} \mathrm{X}_{2}+$ $\mathrm{b}_{3} \mathrm{X}_{3}$ dimana $\mathrm{a}=4,553, \mathrm{~b}_{1}=0,025, \mathrm{~b}_{2}=0,081$, dan $b_{3}=0,039$. Persamaan regresi yang terbentuk adalah signifikansi $\hat{Y}=4,553+$ $0,025 \mathrm{X}_{1}+0,081 \mathrm{X}_{2}+0,039 \mathrm{X}_{3}$.

Dari keempat hipotesis tersebut dapat ditarik kesimpulan bahwa Berdasarkan pengujian hipotesis pertama diperoleh nilai $t$ untuk variabel lingkungan sekolah dengan nilai $t_{\text {hitung }}=6,622$ dengan nilai signifikansi yang diperoleh sebesar 0,000 . Jika nilai $t_{\text {hitung }}>t_{\text {tabel }}$, maka terdapat hubungan yang signifikan, apabila $t_{\text {hitung }}<t_{\text {tabel }}$ maka tidak terdapat hubungan yang signifikan. Nilai $\mathrm{t}_{\text {tabel }}$ pada alpha $5 \%$ adalah $\mathrm{dk}=\mathrm{N}-3$ atau $\mathrm{dk}$ $=83-3=80$, nilai $t_{\text {tabel }}$ yaitu 1,990. Apabila 
dibandingkan $\mathrm{t}_{\text {hitung }} 6,622$ dengan $\mathrm{t}_{\text {tabel }} 1,990$, maka dapat diketahui bahwa nilai $t_{\text {hitung }}>t_{\text {tabel. }}$ Maka dari itu dapat disimpulkan bahwa terdapat kontribusi antara lingkungan sekolah dengan hasil belajar di SMKN 6 Padang.

Berdasarkan pengujian hipotesis kedua diperoleh nilai $t$ untuk variabel efikasi diri dengan nilai $t_{\text {hitung }}=7,806$ dengan nilai signifikansi yang diperoleh sebesar 0,000. Jika nilai $t_{\text {hitung }}>t_{\text {tabel, }}$ maka terdapat hubungan yang signifikan, apabila $\mathrm{t}_{\text {hitung }}<\mathrm{t}_{\text {tabel }}$ maka tidak terdapat hubungan yang signifikan. Nilai tabel pada alpha 5\% adalah $\mathrm{dk}=\mathrm{N}-3$ atau $\mathrm{dk}=83-3=80$, nilai $\mathrm{t}_{\text {tabel }}$ yaitu 1,990. Apabila dibandingkan $t_{\text {hitung }} 7,806$ dengan $t_{\text {tabel }} 1,990$, maka dapat diketahui bahwa nilai $t_{\text {hitung }}>t_{\text {tabel. }}$. Maka dari itu dapat disimpulkan bahwa terdapat kontribusi antara efikasi diri dengan hasil belajar di SMKN 6 Padang.

Berdasarkan pengujian hipotesis ketiga diperoleh nilai $t$ untuk variabel kecerdasan emosional dengan nilai $t_{\text {hitung }}=4,868$ dengan nilai signifikansi yang diperoleh sebesar 0,000 . Jika nilai $t_{\text {hitung }}>t_{\text {tabel }}$, maka terdapat hubungan yang signifikan, apabila $\mathrm{t}_{\text {hitung }}<\mathrm{t}_{\text {tabel }}$ maka tidak terdapat hubungan yang signifikan. Nilai $t_{\text {tabel }}$ pada alpha $5 \%$ adalah $\mathrm{dk}=\mathrm{N}-3$ atau $\mathrm{dk}=83-3=80$, nilai $t_{\text {tabel }}$ yaitu 1,990. Apabila dibandingkan $\mathrm{t}_{\text {hitung }} 4,868$ dengan $\mathrm{t}_{\text {tabel }} 1,990$, maka dapat diketahui bahwa nilai $t_{\text {hitung }}>t_{\text {tabel. }}$. Maka dari itu dapat disimpulkan bahwa terdapat kontribusi antara kecerdasan emosional dengan hasil belajar di SMKN 6 Padang.

Berdasarkan pengujian hipotesis keempat diperoleh nilai statistic signifikansi pada uji $F$ sebesar 27,721 dengan probabilitas 0,000 , karena nilai probabilitas tersebut kecil daripada alpha 0,05 atau pada taraf kepercayaan 95\%. Untuk uji dua pihak, dengan $\mathrm{F}_{\text {tabel }}$ (lampiran 11) didapat sebesar 2,718. Diperoleh nilai $\mathrm{F}_{\text {hitung }}>\mathrm{F}_{\text {tabel }}$ maka $\mathrm{H}_{0}$ ditolak, artinya bahwa terdapat kontribusi antara lingkungan sekolah, efikasi diri dan kecerdasan emosional secara bersama-sama dengan hasil belajar siswa di SMKN 6 Padang. Dengan terdapatnya korelasi yang signifikan maka dapat disimpulkan bahwa lingkungan sekolah, efikasi diri dan kecerdasan emosional secara bersama-sama memberikan kontribusi positif terhadap hasil belajar di SMKN 6 Padang sebesar $51,3 \%$.

\section{Kesimpulan}

Berdasarkan hasil analisis penelitian tentang kontribusi lingkungan sekolah, efikasi diri dan kecerdasan emosional terhadap hasil belajar siswa di SMKN 6 Padang, maka dapat ditarik kesimpulan yaitu: 1) Terdapat kontribusi lingkungan sekolah dengan hasil belajar di SMKN 6 Padang sebesar 35,1\%, 2) Terdapat kontribusi efikasi diri dengan hasil belajar di SMKN 6 Padang sebesar 42,9\%, 3) Terdapat kontribusi kecerdasan emosional dengan hasil belajar di SMKN 6 Padang sebesar 22,6\%, 4) Terdapat kontribusi lingkungan sekolah, efikasi diri dan kecerdasan emosional terhadap hasil belajar siswa di SMKN 6 Padang sebesar 51,3\%. Dapat disimpulkan bahwa lingkungan sekolah, efikasi diri dan kecerdasan emosional terhadap hasil belajar siswa siswa memiliki korelasi yang signifikan pada taraf kesalahan 5\%. Ini menunjukkan bahwa terdapat korelasi yang sangat kuat antara lingkungan sekolah, efikasi diri dan kecerdasan emosional terhadap hasil belajar siswa di SMKN 6 Padang.

\section{Ucapan Terima Kasih}

Terimakasih yang luar biasa saya utarakan kepada kedua orangtua tersayang yang telah memberikan dukungan baik materi maupun moril kepada saya, sehingga saya sampai pada tahap ini. Terimakasih yang tiada hentinya juga saya ucapkan kepada kedua pembimbing yang telah memotivasi dan memberikan bimbingan 
Dianne Wira Suryani ${ }^{1)}$, Prof. Dr. Jalius Jama, M.Ed ${ }^{2)}$

Informatika : Fakultas Sains dan Teknologi

Vol. 8 No. 3 / 2020

2615-1855 (E-ISSN)

2303-2863 (P-ISSN)

Universitas Labuhanbatu

seutuhnya kepada saya dalam penyelesaian jurnal ini. Selanjutnya terimakasih saya sampaikan kepada rekan-rekan pejuang tesis yang bersama-sama memberikan dorongan dan semangat dalam setiap tahapan yang saya jalani. Terakhir, kepada seluruh pihak yang terlibat dalam penyelesaian tesis ini, saya ucapkan terimakasih.

\section{Daftar Pustaka}

[1] Arif Gunarso. 2013. Hasil belajar. Jakarta: Prena Media Group.

[2] Ngalim Purwanto. 2011. Psikologi Pendidikan. Bandung: Alfabeta.

[3] Hasbullah. 2013. Mengenal Lingkungan Sekitar. Jakarta: Tristo.

[4] Dalyono. 2010. Lingkungan Sekolah. Yogyakarta: Diva Press.

[5] Hamalik. 2014. Pemanfaatan Lingkungan Sekolah. Yogyakarta: Diva Press.

[6] Bandura, 2010. Efikasi Diri dan Faktor yang Mempengaruhinya. Yogyakarta: AKY Press.

[7] Ghufron. 2010. Jenis-Jenis Efikasi Diri. Yogyakarta: AKY Press.

[8] Rachmawati. 2011. Kiat Memahami Efikasi Diri Siswa. Yogyakarta: Ombak.

[9] Daniel Goleman. 2015. Kecerdasan Emosional. Jakarta: Rajawali Pers.

[10] Sugiyono. 2013. Metode Penelitian Kuantitatif Kualitatif dan $R \& D$. Bandung: Alfabeta.

[11] Creswell. 2010. Jenis-Jenis Penelitian. Bandung: Alfabeta. 